\title{
Genotoxicity characteristics of reverse diol-epoxides of chrysene
}

\author{
Hansruedi Glatt, Christa Wameling, Sabine Elsberg, \\ Helmut Thomas ${ }^{3}$, Hans Marquardt', Alan Hewer ${ }^{2}$, \\ David H.Phillips ${ }^{2}$, Franz Oesch and Albrecht Seidel
}

Department of Toxicology of the University of Mainz, Obere Zahlbacher Strasse 67, D-6500 Mainz, ${ }^{1}$ Department of Pharmacology of the University of Hamburg, Grindelallee 117, D-2000 Hamburg 13, Germany, ${ }^{2}$ Institute of Cancer Research, Haddow Laboratories, Cotswold Road, Belmont, Sutton SM2 5NG, UK

${ }^{3}$ Present address: Ciba-Geigy AG, Central Toxicology Unit, CH-4002 Basel, Switzerland

Trans-3,4-dihydroxy-3,4-dihydrochrysene (chrysene-3,4-diol), a major metabolite of chrysene, is further metabolized by rat liver enzymes to products which effectively revert the $h$ is $^{-}$ Salmonella typhimurium strain TA98 to histidine prototrophy, but are only weakly mutagenic in strain TA100 and in Chinese hamster V79 cells (acquisition of resistance to 6-thioguanine). The liver enzyme mediated mutagenicity of chrysene-3,4-diol is substantially enhanced in the presence of 1,1,1-trichloropropene 2,3-oxide, an inhibitor of microsomal epoxide hydrolase. The predominant metabolites of chrysene-3,4-diol, namely the anti- and syn-isomers of its 1,2-oxide (termed reverse diol-epoxides), proved to be extraordinarily effective mutagens in S.typhimurium strain TA98, but were only moderately active in strains TA100 and TA104, and in the SOS induction in Escherichia coli PQ37. These genotoxicity spectra in bacteria are completely different from those observed with the bay-region diol-epoxides of chrysene and 3-hydroxychrysene. In V79 cells, the reverse diol-epoxides formed low levels of DNA adducts and were very weak inducers of gene mutations. In M2 mouse prostate cells, however, high numbers of transformed foci were induced by chrysene-3,4-diol and its diastereomeric 1,2-oxides. Chrysene-3,4-diol was somewhat more potent than chrysene1,2-diol. The potency of both reverse diotepoxides was similar to that of the syn-diastereomers of the bay-region diotepoxides of chrysene and 3-hydroxychrysene, but lower than that of their anti-diastereomers. The reverse diol-epoxides of chrysene, unlike the bay-region diol-epoxides, were inactivated by purified microsomal epoxide hydrolase. Noteworthy findings were also made with regard to the chemical stability of the diol-epoxides in buffer, determined from the decline in mutagenicity after preincubation in the absence of the target cells. Despite its lower $\Delta \mathrm{E}_{\text {detoc }} \beta$ value for the formation of the benzylic carbocation, anti-

\footnotetext{
*Abbreviations: anti-chrysene-1,2-diol 3,4-oxide, $r-1, t$-2-dihydroxy-t-3,4-oxy1,2, 3,4-tetrahydrochrysene; anti-chrysene-3,4-diol 1,2-oxide, r-4,1-3-dihydroxy$t-1,2$-oxy-1,2,3,4-tetrahydrochrysene; anti-9-hydroxychrysene-1,2-diol 3,4-oxide, 9-hydroxy-r-1,t-2-dihydroxy-t-3,4-oxy-1,2,3,4-tetrahydrochrysene; syn-chrysene1, 2-diol 3,4-oxide, $r$-1, t-2-dihydroxy-c-3,4-oxy-1,2,3,4-tetrahydrochrysene; synchrysene-3,4-diof 1,2-oxide, r-4,t-3-dihydroxy-c-1,2-oxy-1,2,3,4-tetrahydrochrysene; sym-9-hydroxychrysene-1,2-diol 3,4-oxide, 9-hydroxy-r-1,s-2-dibydroxy$c$-3,4-oxy-1,2,3,4-tetrahydrochrysene; chrysene-1,2-diol, trans-1,2-dihydroxy1, 2-dihydrochrysene; ctrysene-3,4-diol, trans-3,4-dihydroxy-3,4-dihydrochrysene; PBS-HEPES, Dulbecoo's phosphate-buffered saline additionally containing $10 \mathrm{mM}$ of 4-(2-hydroxyethyl)-1-piperazine ethanesulfonic acid (pH 7.4).
}

chrysene-3,4-diol 1,2-oxide was shorter-lived ( $t_{1 / 2}=46 \mathrm{~min}$ ) than anti-chrysene-1,2-diol 3,4-oxide ( $t_{1 / 2}=74 \mathrm{~min}$ ). Unlike other investigated diastereomeric pairs of diol-epoxides, it was also shorter-lived than its syn-diastereomer $\left(t_{1 / 2}=340 \mathrm{~min}\right)$.

\section{Introduction}

A number of chrysene metabolites were investigated for mutagenicity by Wood and coworkers $(1,2)$ and by ourselves $(3,4)$. These studies indicated that bay-region diol-epoxides, including derivatives with an additional, phenolic hydroxyl group in the 9-position, are important in the mutagenicity in Salmonella typhimurium TA100 (reversion to histidine prototrophy) and in Chinese hamster V79 cells (acquisition of resistance toward 6-thioguanine). Strikingly, however, these diol-epoxides are poor mutagens in $S$. typhimurium TA98, whereas strong effects are observed with trans-3,4-dihydroxy-3,4-dihydrochrysene (chrysene-3,4-diol*), examined in the presence of a rat liver postmitochondrial enzyme preparation (3). Chrysene-3,4-diol is a major metabolite of chrysene in liver microsomes from rats treated with various enzyme inducers and in human epithelial bronchial cells $(5-8)$. When incubated with a rat liver microsomal or purified cytochrome P450c (CYP1A1) system, chrysene-3,4-diol is predominantly metabolized at the olefinic double bond adjacent to the diol group $(9,10)$. From the pattern of tetraols detected it was concluded that the diol is oxidized to the syn- as well as to the anti-diastereomer of the vicinal diolepoxide. These 'reverse' diol-epoxides (structural formulas shown in Figure 1) have now become available in larger quantities by means of stereospecific synthesis (11). We report here on some unusual genotoxicity characteristics of these chrysene-3,4-diol 1,2-oxides, concerning genotoxicity spectra, stability in buffer and metabolic detoxification. They also have been investigated in a cell transformation assay. In addition, using the ${ }^{32} \mathrm{P}$ postlabelling method, we have studied the covalent binding to isolated DNA as well as to the DNA of target cells of mutagenicity assays.

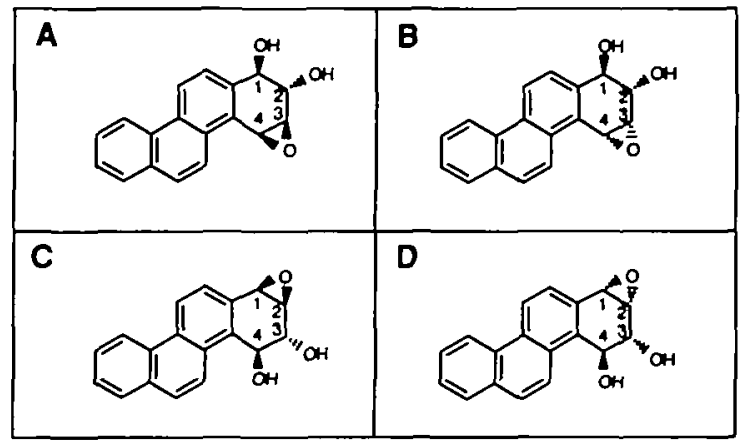

Fig. 1. Structures of chrysene diol-epoxides; A syn-chrysene-1,2-diol 3,4-oxide, B anti-chrysene-1,2-diol 3,4-oxide, C syn-chrysene-3,4-diol 1,2-oxide. D anti-chrysene-3,4-diol 1,2-oxide. 


\section{Materials and methods}

\section{Chemicals}

In preparation of the diastereomeric reverse diol-epoxides of chrysene, chrysene 3,4-quinone was a key intermediate, which was synthesized as follows. Taking advantage of the high yields observed for the oxidative photocyclization of suitably substituted 1-(1-naphthyl)-2-phenyl ethylenes (12), the carechol dimethylether 3,4-dimethoxychrysene was obtained in 7 steps starting from 2,3-dimethoxybenzaldehyde, with a total yield of $22 \%$ (13). Cleavage of the dimethylether with boron tribromide and subsecuent oxidation with silver carbonate gave chrysene-3,4-quinone from which the chrysene-3,4-diol was prepared as previously described for similar o-quinones (14). Direct epoxidation of this bay-region diol with dimethyldioxirane (15) under mild conditions proceeded stereospecifically to furnish the pure syn-chrysene-3,4-diol 1,2-oxide (11). The anti-diastereomer was synthesized from trans-3,4-diacetoxy-3,4-dihydrochrysene, as described elsewhere (11). The syntheses and analytical data of the bay-region diol-epoxides of chrysene and 3-hydroxychrysene were previously reported $(12,16)$. The high resolution proton magnetic resonance spectra $(400 \mathrm{MHz})$ were in full accordance with the assumed chemical structure of the test compounds. The purity of all test compounds used was $>98 \%$, as estimated from thin layer chromatographic analyses.

Diol-epoxides can exist in two interconvertible conformations, which are termed by Sayer et al. (17) as 'aligned' and 'nonaligned'. Varistions in the extent to which these conformations are populated can explain in part the differences in the chemical reactivity of the two possible diastercomers of diol-epoxides $(17,18)$. Inspection of the proton magnetic resonance spectra revealed that the synchrysene-3,4-diol 1,2-oxide preferentially adopts a nonaligned conformation, in which the hydroxyl groups are oriented pseudodiaxially (11). In contrast, no clear preference for either conformation could be observed for the anti-diastereomer.

Preparation of $S 9$ mix

Male Sprague-Dawley rats $(200-300 \mathrm{~g})$ were given a single i.p. injection of Aroclor $1254(500 \mathrm{mg} / \mathrm{kg}$ body wt; Aroclor was diluted with sunflower oil 1:5, $v / v) 6$ days before they were killed. The livers were homogenized in 3 vol. of sterile, cold $\mathrm{KCl}(150 \mathrm{mM})$ containing $10 \mathrm{mM}$ sodium phosphate buffer $(\mathrm{pH} 7.4)$ in a Potter-Elvehjem glass/teflon homogenizer. The homogenate was centrifuged at $9000 \mathrm{~g}$ for $10 \mathrm{~min}$. One volume of the resulting supernatant (59) fraction was mixed with 2 vol. of a solution that contained $12 \mathrm{mM} \mathrm{MgCl}, 50 \mathrm{mM} \mathrm{KCl}$, $6 \mathrm{mM}$ NADP $^{+}, 7.5 \mathrm{mM}$ glucose 6 -phosphate and $75 \mathrm{mM}$ sodium phosphate buffer, $\mathrm{pH}$ 7.4. This preparation, which is termed $\mathrm{S} 9 \mathrm{mix}$, was always freshly prepared from rats killed on the day of the mutagenicity experiment.

\section{Purification of eparide hydrolase}

Microsomal epoxide hydrolase was purified from the liver of adult male Sprague-Dawley rats (19). The preparation used contained cytochromes P450 $(\sim 20 \%)$, which would however be insctive under the experimental conditions due to lack of the cofacor, NADPH. The specific activity of the purified enzyme toward styrene axide was $410 \mathrm{mmol} / \mathrm{min} / \mathrm{mg}$ protein under the conditions described (19). One unit is defined as the amount of enzyme which hydrolyzes 1 nmol styrene oxide/min.

\section{Mutagenicity in bacteria}

S.typhimurium strains were grown overnight in medium A (25 g Oxoid Nutrient Broth No. 2M). For inoculation, stock cultures (which had been stored at $-70^{\circ} \mathrm{C}$ ) were used. Before the experiment, bacteria were centrifuged, resuspended in medium $\mathrm{B}$ ( $1.6 \mathrm{~g}$ Bacto nutrient broch and $5 \mathrm{~g} \mathrm{NaCl} / 1)$ and adjusted nephelometrically to a titer of 1 to $2 \times 10^{9}$ bacteria (colony forming units)/ml.

Mutagenicity of chrysene-3,4-diol was determined using a minor modification of the plate-incorporation assay described by Maron and Ames (20). The test compound (in $10 \mu \mathrm{l}$ dimethylsulfoxide), the epoxide hydrolase inhibitor, 1,1,1-trichloropropene 2,3-oxide (21) $(2.6 \mu \mathrm{mol}$ in $10 \mu$ dimethylsulfoxide, or the solvent only), $500 \mu \mathrm{l} 99 \mathrm{mix}$ (the S9 fraction being diluted with homogenization buffer to obtain the desired protein concentration), $100 \mu$ lof the bacterial suspension, and $2 \mathrm{ml}$ of $45^{\circ} \mathrm{C}$ warm top agar $(0.55 \% \mathrm{agar}, 0.55 \% \mathrm{NaCl}, 50 \mu \mathrm{M}$ histidine, $50 \mu \mathrm{M}$ tryptophan, $50 \mu \mathrm{M}$ biotin, $25 \mathrm{mM}$ sodium phosphate buffer, $\mathrm{pH} 7.4$ ) were mixed in a test nube and poured onto a Petri dish containing $22 \mathrm{ml}$ of minimal agar (1.5\% agar, Vogel-Bonner E medium, with $2 \%$ glucose). After incubation for 2-3 days in the dark, the colonies (his ${ }^{+}$revertants) were counted.

In the experiments in which the mutagenicity of the diol- and triol-epoxides was tested, a slightly modified protocol was used involving liquid preincubation. The bacteria and the test compound (dissolved in $20 \mu \mathrm{l}$ acetone/triethylamine, $1000: 1, v / v)$ were added sequentially to a glass tube containing $500 \mu \mathrm{l}$ buffer $\left(150 \mathrm{mM} \mathrm{KCl}, 10 \mathrm{mM}\right.$ sodium phosphate buffer, $\mathrm{pH} 7.4$ ) at $37^{\circ} \mathrm{C}$. Twenty min later, top agar was added and the experiment continued as described above. In other experiments the stability of the epoxides in the incubation buffer was studied. Here also the liquid preincubation assay was used but with the modification that the bacteria were added to the buffer $0-182 \mathrm{~min}$ after the addition of the test compound.

In the experiments in which the effect of purified epoxide hydrolase on the mutagenicity was studied, enzyme and test compound were incubated in the buffer at $37^{\circ} \mathrm{C}$ for $20 \mathrm{~min}(22)$. Then bacteria, after an additional $20 \mathrm{~min}$ top agar, were added and the experiment continued as described above.

Specific mutagenicities (revertants per nmol) were calculated from the initial part of the dose-response curve as described (23).

\section{SOS chromotest}

The E.coli strain $\mathrm{PQ} 37$ was kindly provided by M.Hofnung, Paris. In this strain, the $\beta$-galactosidase gene is under the control of the SOS promoter. Induction of an SOS response was studied using the protocol of Quillardet and Hofnung (24) with minor modification. Bacteria were grown for about $7 \mathrm{~h}$ in Lamp medium ( $25 \mathrm{~g}$ Oxoid nutrient broth No. 2 and $20 \mathrm{mg}$ ampicillin/l) at $37^{\circ} \mathrm{C}$ with shaking (200 r.p.m.). The culture was then diluted 1:10 and grown until it reached a density of $4 \times 10^{9}$ colony-forming units/ml, as estimated by nephelometry. This culture was diluted 1:5 with Lamp medium, and $250 \mu$ lof the resulting bacterial suspension were put into each incubation tube. The test compound, dissolved in $10 \mu \mathrm{l}$ acetone:triethylamine $(1000: 1, \mathrm{v} / \mathrm{v})$, was then added. After incubation for $2 \mathrm{~h}$ at $37^{\circ} \mathrm{C}$ with shaking ( 150 r.p.m.), enzyme activities were determined, with two incubations per experimental condition.

For the determination of $\beta$-galactosidase activity, $1.25 \mathrm{ml}$ of $Z$ buffer $(150 \mathrm{mM}$ $\mathrm{NaH}_{2} \mathrm{PO}_{4}, 150 \mathrm{mM} \mathrm{Na} \mathrm{HPO}_{4}, 1 \mathrm{mM} \mathrm{MgSO}, 1 \mathrm{~g} / 1$ sodium dodecyl sulfate, 2.7 $\mathrm{militer} \beta$-mercaptoechanol) were addod to the incubation. After $5 \mathrm{~min}$, the substrate (1.2 mg o-nitrophenyl- $\beta$-D-galactopyranoside in $250 \mu \mathrm{l} \mathrm{Z}$ buffer) was added. The reaction was stopped $30 \mathrm{~min}$ later by the addition of $1 \mathrm{ml} \mathrm{Na}_{2} \mathrm{CO}_{3}$ solution $(1 \mathrm{M})$ and the absorbance at $420 \mathrm{~nm}$ was read.

For the determination of alkaline phosphatase, $1.25 \mathrm{ml}$ of $\mathrm{T}$ buffer $[1 \mathrm{M}$ tris(hydroxymethyl)aminomethane-HCl buffer, $\mathrm{pH} 8.8,1 \mathrm{~g} / 1$ sodium dodecyl sulfate] was added to the incubation. After $5 \mathrm{~min}$, the substrate $(1.2 \mathrm{mg} p$ nitrophenyl phosphate disodium in $250 \mu \mathrm{l}$ T buffer) was added. The reaction was stopped $10 \mathrm{~min}$ later by the addition of $500 \mu 12 \mathrm{M} \mathrm{HCl}$, followed $5 \mathrm{~min}$ later by the addition of $500 \mu 12 \mathrm{M} \mathrm{NaOH}$. The absorbance at $420 \mathrm{~nm}$ was then read.

The induction factor is defined as the ratio of $\beta$-galactosidase and alkaline phosphatase activity of a treatment group, divided by the corresponding value of the solvent control. As a measure of the potency of a compound in this assay, the slope of the induction factor as a function of the dose was calculated.

In all experiments, benzo[a]pyrene 4,5-oxide (50 ng) was used as a positive control. It produced induction factors between 4.8 and 7.0 in the experiments shown.

\section{Mutagenicity in V79 cells}

Chinese hamster V79 cells were maintained in Dulbecco's modified minimum essential medium supplemented with fetal calf serum $(5 \%)$, penicillin $(100$ units $/ \mathrm{ml})$, and streptomycin $(100 \mu \mathrm{g} / \mathrm{ml})$. The cells were grown at $37^{\circ} \mathrm{C}$ in a humidified atmosphere containing $5 \% \mathrm{CO}_{2}$. The protocol used for the determinattion of mutagenicity was identical to that used in previous studies $(3,4,16,25)$. A total of $1.5 \times 10^{6}$ cells and $30 \mathrm{ml}$ medium were added to each $150 \mathrm{~cm}^{2}$ dish on day 1 . After $18 \mathrm{~h}$, the medium was replaced by $18 \mathrm{ml}$ of PBS-HEPES, and the test compound (dissolved in $60 \mu \mathrm{l}$ acetone/triethylamine, 1000:1, v/v) was added. Test compound and buffer were removed $2 \mathrm{~h}$ later. After washing with PBS-HEPES, medium $(30 \mathrm{ml})$ was added to the culture. On day 4 , the cells were detsiched. Solvent controls yielded 8.3-9.7 $\times 10^{7}$ cells in all experiments of this study. As a measure for toxicity, the number of cells of the trealment groups was expressed as a percent of the solvent control. The cells were then subcultured at a density of $3 \times 10^{6}$ per $150 \mathrm{~cm}^{2}$ dish. On day 8 , they were again subcultured, at a density of $10^{6}$ per $150 \mathrm{~cm}^{2}$ dish in medium containing 6-thioguanine $(7 \mu \mathrm{g} / \mathrm{ml})$ for the selection of mutants (6 replicate plates) and, at a density of $100 \mathrm{cells} / 22 \mathrm{~cm}^{2}$ dish in modium without 6-thioguanine, for the determination of the cloning efficiency ( 3 replicate plates). The plates were fixed and stained with Giemsa, and the colonies were counted after about 7 days (cloning efficiency plates) or 10 days (6-thioguanine plates).

Transformation of $M 2$ cells

Cells of the M2 clone of mouse fibroblasts, originally established as a line from C3H mouse prostate cells, are susceptible to malignant transformation (26). In the present work they were used between the 13 th and 15 th passage. They were cultured in Eagle's basal medium supplemented with fetal calf serum (10\%), penicillin $(100 \mathrm{units} / \mathrm{ml})$, and stroptormycin $(100 \mu \mathrm{q} / \mathrm{ml})$. For the assay of transform? tion and for the determination of the cloning efficiency, 1000 and 100 cells respectively, were plated into $22 \mathrm{~cm}^{2}$ plastic Petri dishes and after $24 \mathrm{~h}$ treated with the test compounds. After a further $24 \mathrm{~h}$, the compounds were removed by a change of the medium; thereafter, the medium was changed twice weekly. After 7-14 days, the dishes plated with 100 cells were fixed and stained, and the colonies were counted to determine the cloning efficiency. After 56 days, the dishes plated with 1000 cells were fixed, stained, and scored for transformed, piled-up foci.

The number of induced foci per dish, at the optimal exposure concentration, was used as a measure of the transformation efficacy. In order to obtain a measure for the pocency of the transformation activity, the number of incusced foci per dish was divided by the exposure concentration. The values presented in Table 
I refer to the concentration for which this value was highest; usually 2-3 neighboring concentrations led to similar values (differing by factors of $<2$ ). ${ }^{32} P$-Postlabelling analysis

V79 cells were exposed to the test compounds exactly as in the corresponding mutagenicity experiments. The DNA was isolated as described (27). In order to prepare DNA samples chemically modified by the diol-epoxides, a solution of salmon sperm DNA $(100 \mu \mathrm{g})$ in tris(hydroxymethyl)aminomethane- $\mathrm{HCl}$ $(0.01 \mathrm{M}, \mathrm{pH} 7.4,200 \mu \mathrm{l})$ was mixed with a solution of either anti- or $5 y$ chrysene-3,4-diol 1,2-oxide $(10 \mu \mathrm{g})$ in ethanol $(100 \mu \mathrm{l})$. The reaction mixtures were stored in the dark at room temperature for $17 \mathrm{~h}$, then extracted with ether $(8 \times 1 \mathrm{vol})$. Resichual ether was removed from the aqueous phases under a stream of nitrogen, and the DNA solutions were stored frozen prior to ${ }^{32} \mathrm{P}$-postlabelling. DNA samples $(0.17 \mu \mathrm{g})$ that had been digested to deoxyribonucleoside 3 '-monophosphates by micrococcal nurclease and spleen phosphodiesterase were $5^{\prime}$-labelled with $\left[{ }^{32} \mathrm{P}\right]$ ortho-phosphate by incubation with $\left[\gamma^{-32} \mathrm{P}\right] \mathrm{ATP}$ and polynucleotide kinase as described (27). In some experiments DNA digests (4 $\mu \mathrm{g})$ were further incubated with nuclease $P_{1}$ prior to postlabelling in the absence of carrier ATP (28). Separation of unmodified 32P-labelled bisnucleotides and resolution of ${ }^{32} \mathrm{P}$-labelled adducts were carried out on polyethylene iminecellulose thin layer chromatographic sheets as described $(4,25)$. The chromatography shets were developed overnight with $1 \mathrm{M}$ sodium phosphate (pH 6.0) onto a filter paper wick and then, after removal of the wick, in the reverse direction (from bottom to top of the chromatograms shown in Figure 6) with $3.5 \mathrm{M}$ lithium formate $-8.5 \mathrm{M}$ urea $(\mathrm{pH} 3.5)$. The sheets were then developed in the second dimension (left to right, Figure 6) first with $0.8 \mathrm{M} \mathrm{LiCl}-0.5 \mathrm{M}$ tris(hydroxymethyl)aminomethane- $\mathrm{HCl}-8.5 \mathrm{M}$ urea $(\mathrm{pH} 8.0)$, and then with $1.7 \mathrm{M}$ sodium phosphate ( $\mathrm{pH} 6.0$ ). The radioactivity present in the spots on the chromatograms was determined by Cerenkov counting of the excized areas. The extent of modification of the DNA was calculated from the ratio of this figure to the amount of ${ }^{32} \mathrm{P}$ incorporated into the whole DNA digest, determined by chromatography of an aliquot of the latter and Cerenkov counting of the normal nucleotides (29). This chromatographic procedure did not reveal the presence of any detectable undigested DNA fragments.

Comparability with results of previous studies

The methods used here are identical to those in previous studies on mutagenic, SOS-inducing and cell-transforming activities of chrysene metabolites $(3,16)$ and on the detoxification of epoxides by purified microsomal epoxide hydrolase (22). A slight modification had to be used for the postlabelling of the DNA adducts of target cells, due to low adduct levels. Nevertheless the results were made comparable to those of the previous study (4) by using both procedures with chemically modified salmon sperm DNA for standardization.

\section{Results}

\section{Mutagenicity of chrysene-3,4-diol}

We have already published concentration-response curves of the mutagenicity in S.typhimurium TA98 and TA100, and in V79 cells (3). Effects were observed only in the presence of liver enzymes, and strong responses were limited to strain TA98. The mutagenicity of a constant intermediate dose of chrysene-3,4-diol in strain TA98, as a function of the concentration of $\$ 9$ enzymes, is shown in Figure 2. The maximal response was observed at a relatively low $\$ 9$ concentration. At higher $\$ 9$ concentrations, the mutagenicity response declined without any sign of toxicity (as judged from the his ${ }^{-}$background lawn). Addition of 1,1,1-trichloropropene 2,3-oxide, a potent inhibitor of microsomal epoxide hydrolase (21), enhanced the liver $\$ 9$ mixmediated mutagenicity of chrysene-3,4-diol. The enhancement was moderate at low $\$ 9$ concentrations, but strong (up to 10-fold) at high $\$ 9$ concentrations and therefore high levels of microsomal epoxide hydrolase.

Mutagenicity of reverse diol-epaxides, as compared to bay-region diol-epoxides and triol-epoxides, in 4 strains of S.typhimurium anti-Chrysene-3,4-diol 1,2-oxide and its syn-diastereomer proved to be extraordinarily effective mutagens in strain TA98, enhancing the number of mutants per plate up to 600 - and 300 -fold above the background level respectively (Figure 3). Mutagenicity was also observed in the other 3 bacterial strains used, but the effects were substantially weaker. The results, expressed as revertants per nmol test compound, are summarized, and

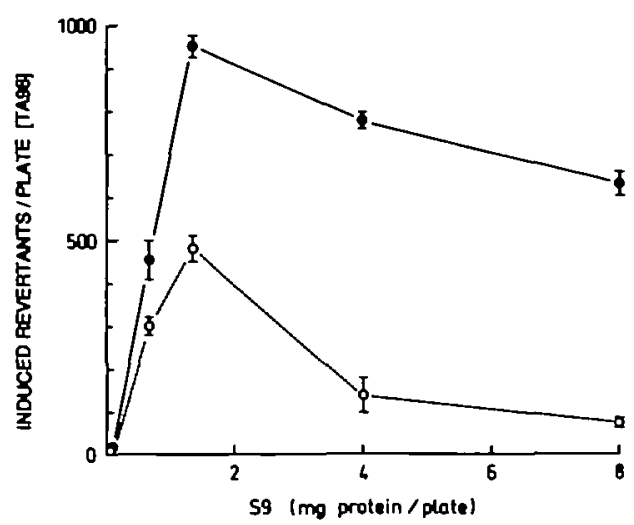

Fig. 2. Effect of the epoxide hydrolase inhibitor, 1,1,1-trichloropropene 2,3-oxide $(2.6 \mu \mathrm{mol}$ per plate) on the rat liver $\$ 9 \mathrm{mix}$-modiated mutagenicity of chrysene-3,4-diol (35 $\mu \mathrm{g}$ per plate). Spontaneous mutants $(51-67)$ were subtracted. Values are mean \pm S.E. from 3 plates. - , with epoxide hydrolase inhibitor; $O$, without inhibitor.
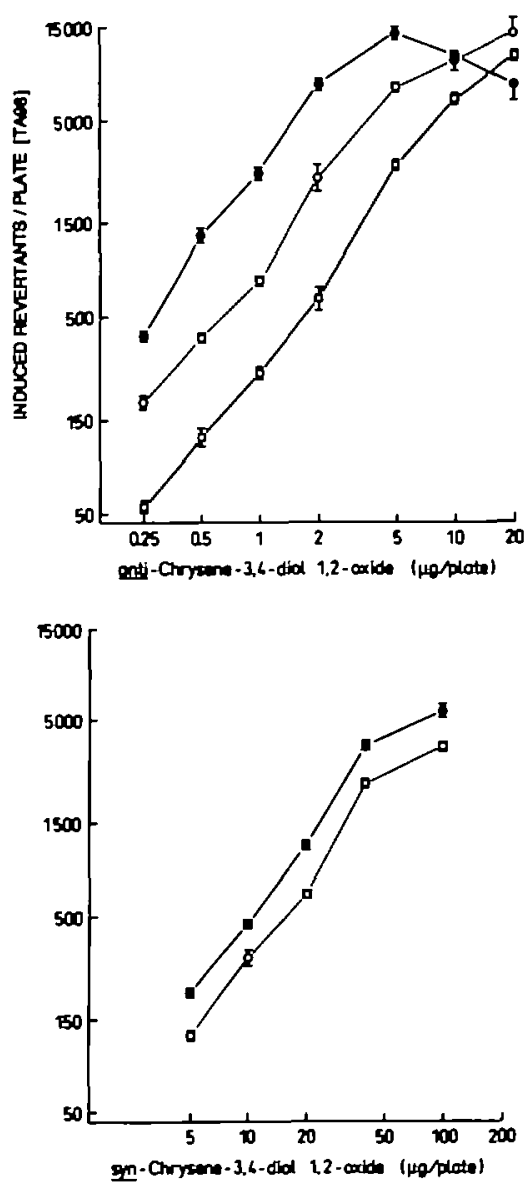

Fig. 3. Concentration-response curves of the mutagenicity of antichrysene-3,4-diol 1,2-oxide (upper panel) and syn-chrysene-3,4-diol 1,2-oxide (lower panel) in Salmonella typhimurium TA98, and stability of the test compounds in aqueous medium. The test compound was added to a solution of $\mathrm{KCl}(150 \mathrm{mM})$ in sodium phosphate buffer $(10 \mathrm{mM}, \mathrm{pH} 7.4)$, which was kept at $37^{\circ} \mathrm{C}, 2 \mathrm{~min}\left({ }^{\circ}\right), 62 \mathrm{~min}(\mathrm{O}$, anti-diastereomer), $122 \mathrm{~min}(\square)$ or $182 \mathrm{~min}(\mathrm{O}, \mathrm{syn}$-diastereomer) before the bacteria. Spontaneous revertants (23) were subtracted. Values are mean \pm S.E. from 3 incubations. From the shifts of the concentration-response curves, halflifes of 46 and $340 \mathrm{~min}$ were calculated for the anti- and syn-diastereomers, respectively.

compared to those of the bay-region diol-epoxides and triolepoxides in Table I. The bay-region diol-epoxides preferentially reverted strains TA100 and TA104, the numbers of revertants 
Tabłe I. $\Delta \mathrm{E}_{\text {detoc }}$ value, half-life, response in the SOS chromotest, mutagenicity in Salmonella typhimurium and V79 Chinese hamster cells, and transforming activity in mouse $\mathrm{M} 2$ cells of chrysene diol-epoxides

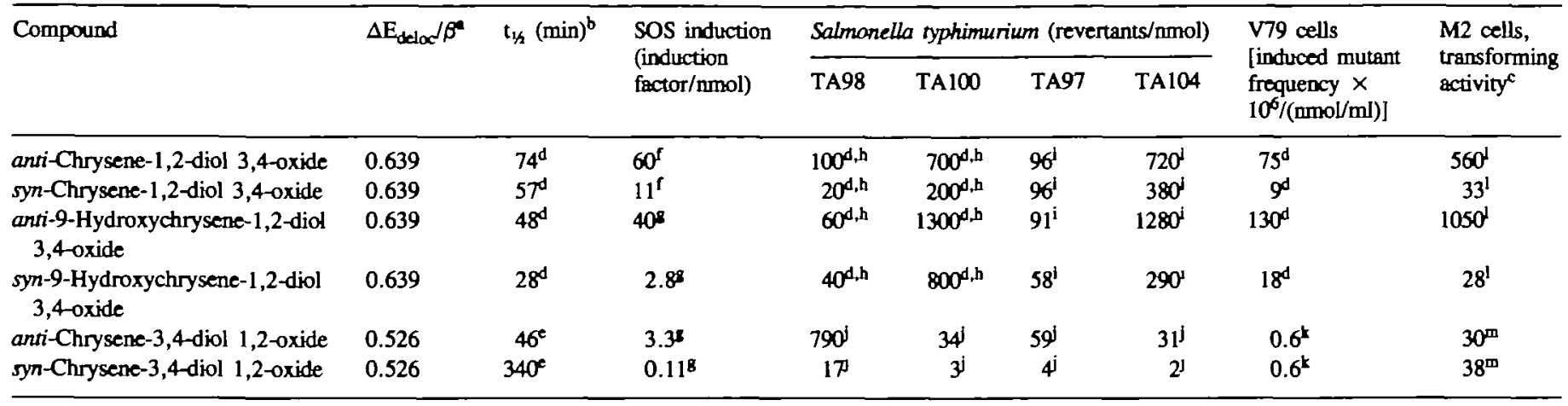

- $\Delta \mathrm{E}_{\text {deba }} / \beta$ is a quantum chemical parameter that estimates the relative ease of ring-opening of the epoxide at the benzylic position to form a resonance-stabilized carbocation. $\Delta \mathrm{E}_{\text {deloc }} / \beta$ values were calculated using the pertubational molecular orbital model of Dewar (43)

${ }^{b} \mathrm{Calculated}$ from the decline in mutagenic activity after preincubation of the test compound in phosphate-buffered saline at $37^{\circ} \mathrm{C}$ in the absence of bacteria.

${ }^{c}$ Units are [(induced foci/dish) $/(\mu \mathrm{mol}$ test compound/ml $\left.)\right]$.

dData taken from a preceding paper (3).

"Calculated from the data presented in Figure 3.

'Data taken from a preceding paper (16).

Calculated from the curves presented in Figure 5.

b,i.JValues determined in the same experiment are marked with the same letter. Intraexperimental S.E. amounted to 1 to $12 \%$ of the means. All compounds were studied in strains TA98 and TA100 in at least 2 separate experiments. The figures for different experiments varied by factors $<2$.

${ }^{k}$ Calculated by using linear regression analysis from the data presented in Table 2.

'Calculated from the data published in a preceding paper (3).

mCalculated from the data presented in Table 3.

induced per nmol being 7-22 times the value in strain TA98. The reverse strain preference, to a similar quantitative extent, was detected with the reverse diol-epoxides. It is therefore not surprising that the order of the mutagenic potency of the six investigated epoxides depended on the bacterial strain considered. In strain TA98, anti-chrysene-3,4-diol 1,2-oxide was by far the most active. In strains TA100 and TA104, anti-9-hydroxychrysene-1,2-diol 3,4-oxide exhibited the highest potency. Strain TA97 showed low responsiveness towards all six investigated epoxides.

\section{Stability of the diol-epoxides in physiological buffer}

In order to estimate the stability of diol-epoxides under mutagenicity assay conditions, they were preincubated for various periods in buffer $(150 \mathrm{mM} \mathrm{KCl}, 10 \mathrm{mM}$ sodium phosphate buffer, pH 7.4) at $37^{\circ} \mathrm{C}$ before addition of the bacteria. From the shift of the concentration-response curves (Figure 3), halflives were calculated (Table I). Among the syn-isomers, the reverse diol-epoxide was substantially more stable than the bayregion diol-epoxide. The results agree with the $\Delta \mathrm{E}_{\text {detod }} / \beta$ values for the formation of the corresponding benzylic carbocations. Strikingly, however, the anti-isomers did not follow this prediction, in that the reverse diol-epoxide was shorter-lived than the bay-region diol-epoxide. Moreover, anti-chrysene-3,4-diol 1,2-oxide was also shorter-lived than its syn-diastereomer, which is not the case with other investigated diastereomeric pairs of diol-epoxides which have been investigated (16).

Effect of purified microsomal epoxide hydrolase on the mutagenicity of diol-epoxides

About equimutagenic concentrations of diol-epoxides, from the linear part of the concentration-response curves, were preincubated in the presence of purified microsomal epoxide hydrolase before addition of the bacteria. The mutagenicity of the bay-region diol-epoxides was not affected by the presence of the enzyme, whereas that of the reverse diol-epoxides was reduced (Figure 4). The amount of enzyme required for a $50 \%$ decrease in mutagenicity of anti-chrysene-3,4-diol 1,2-oxide 14

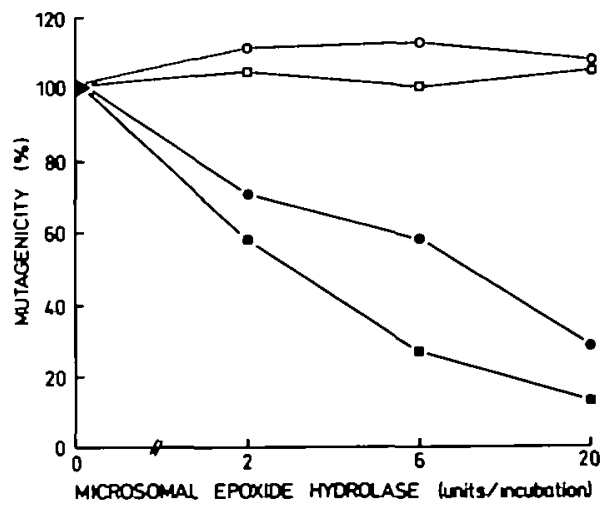

Fig. 4. Effect of purified microsomal epoxide hydrolase on the mutagenicity of anti-chrysene-1,2-diol 3,4-oxide (O), syn-chrysene-1,2-diol 3,4-oxide (D), anti-chrysene-3,4-diol 1,2-oxide (O), and syn-chrysene-3,4-diol 1,2-oxide (a). The number of mutants above control induced by the test compound in the presence of the enzyme is expressed as a percent of the corresponding value without enzyme. The absolute numbers of colonies in the absence of enzyme were $223 \pm 6$ (mean \pm S.E. from 6 plates) for the solvent control with strain TA100, $26 \pm 2$ for the solvent control with strain TA98, $832 \pm 31$ for anti-chrysene-1,2-diol 3,4-oxide $(0.3 \mu \mathrm{g}$, TA 100), $1406 \pm 38$ for syn-chrysene-1,2-diol 3,4-oxide (1.5 $\mu \mathrm{g}$, TA100), $1358 \pm 10$ for anti-chrysene-3,4-diol 1,2-oxide (1.5 $\mu \mathrm{g}$, TA98) and $897 \pm 33$ for syn-chrysene-3,4-diol 1,2-oxide ( $25 \mu \mathrm{g}$. TA98). In the presence of enzyme triplicate incubations were carried out. The specific activity of the purified enzyme was $\mathbf{4 1 0}$ units per mg protein.

$(1.5 \mu \mathrm{g})$ and syn-chrysene-3,4-diol 1,2-oxide $(25 \mu \mathrm{g})$ was about 10 and 30 times that needed for a $50 \%$ detoxification of benz [a] anthracene 5,6-oxide $(1 \mu \mathrm{g})(22)$, which is an excellent substrate. It is unlikely that a non-specific mechanism, eg. covalent binding to the protein, accounted for this effect, since $1 \mathrm{~mol}$ of epoxide hydrolase inactivated up to 26 and $600 \mathrm{~mol}$ of anti- and syn-chrysene-3,4-diol 1,2-oxide respectively.

\section{SOS chromotest}

We have previously investigated a series of diol-epoxides, including the bay-region diol-epoxides of chrysene, on the 

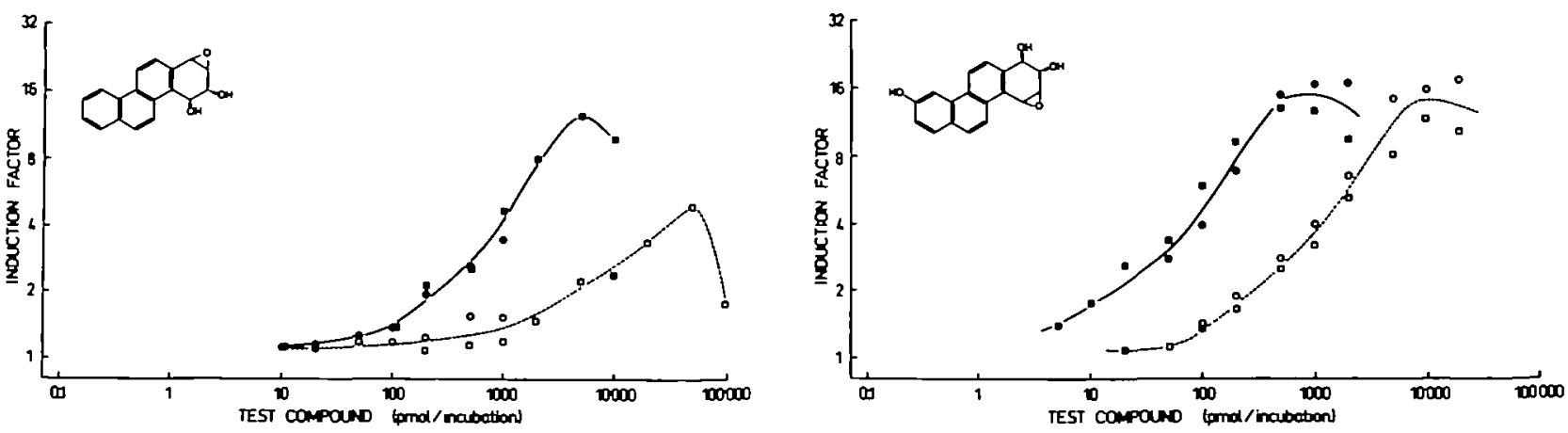

Fig. 5. Induction of SOS response in Escherichia coli PQ37 by anti-diastereomers (solid symbols) and syn-diastereomers (open symbols) of chrysene-3,4-diol 1,2-oxides (left) and 9-hydroxychrysene-1,2-diol 3,4-oxides (right). Circles and squares represent various experiments, conducted on separate occasions. Decreases in alkaline phosphatase activity (indicating cytotoxicity) maximally contributed a factor of 1.5 to the induction factor. Dose-response curves for the bay-region diot-epoxides of chrysene were published previously (16). A summary of the results is contained in Table I.

\begin{tabular}{|c|c|c|c|c|}
\hline \multirow[t]{2}{*}{ Treatment } & \multirow{2}{*}{$\begin{array}{l}\text { Cell number } \\
\text { ( } \% \text { control) }\end{array}$} & \multirow{2}{*}{$\begin{array}{l}10^{6} \times \text { mutant } \\
\text { frequency }\end{array}$} & \multicolumn{2}{|c|}{ pmol adduct/mg DNA } \\
\hline & & & uncorrected & corrected \\
\hline Solvent only & 100 & $4 \pm 1(6)$ & - & - \\
\hline \multicolumn{5}{|c|}{ anti-Chrysene-3,4-diol 1,2-oxide } \\
\hline 10 & 62 & $11 \pm 3(2)$ & $0.15 \pm 0.01$ & $0.90 \pm 0.07$ \\
\hline 20 & $1-22$ & $15 \pm 2(2)$ & $0.28 \pm 0.05$ & $1.70 \pm 0.31$ \\
\hline 35 & $<1$ & - & n.t. & n.t. \\
\hline \multicolumn{5}{|c|}{ syn-Chrysene-3,4-diol 1,2-oxide } \\
\hline $5 \mu \mathrm{M}$ & $83-99$ & $5 \pm 1(3)$ & n.t. & n.t. \\
\hline \multicolumn{5}{|c|}{ anti-Chrysene-1,2-diol 3,4-oxide } \\
\hline $5 \mu \mathrm{M}$ & $37-76$ & $672 \pm 74(3)$ & n.t. ${ }^{b}$ & n.t. ${ }^{b, c}$ \\
\hline
\end{tabular}

"Compiled from 3 separate experiments. For the mumber of surviving cells, ranges are given, due to marked imterexperimental variation. Values for mutant frequencies are means \pm S.E. from the indicated number of separate cultures. Linear regression analyses demonstrated high statistical significance $(P<0.01)$ for the increases in the mutant frequencies with both reverse diol-epoxides. Values for adduct levels are mean \pm S.E. from 2 determinations, using the nuclease $P_{1}$ digestion modification of the ${ }^{32} \mathrm{P}$-postlabelling method (column headed uncorrected). This modification had to be used because of the low level of adducts. To make the figures comparable with data obtained by the standard method, they were multiplied by 6 (anti-diastereomer) or 1.4 (syn-diastereomer) (column headed corrected). The correction factors were determined by applying both methods to salmon sperm DNA treated with these epoxides.

bot tested in this experiment.

¿Using the known concentration-response curves for the induction of mutations and the formation of DNA adducts (ref. 4), 34.9 pmol adducts per mg DNA would be expected at this mutation level.

induction of an SOS response in E.coli PQ37 (16). The reverse diol-epoxides of chrysene and the bay-region diol-epoxides of 3-hydroxychrysene were active in this system as well (Figure 5 ). The comparison of the slopes of the dose-response curves (Table I) shows that in all 3 pairs the anti-diastereomer was markedly more active than the syn-diastereomer, that the bayregion diol-epoxides of chrysene were somewhat more active than the corresponding triol-epoxides, and that the reverse diolepoxides were the least active.

\section{Mutagenicity and covalent DNA-binding of reverse diol-epoxides in $V 79$ cells}

The reverse diol-epoxides showed strong cytotoxic effects, but only weak mutagenic effects in V79 cells (Table II). DNA adducts in these cells were determined concurrently with the mutagenicity.
The levels of adducts were close to the limit of detection using the standard ${ }^{32} \mathrm{P}$-postlabelling method (data not shown) and thus not readily quantifiable, but were readily detectable using the nuclease $P_{1}$ digestion method of sensitivity enhancement (Figure $6 \mathrm{a}, \mathrm{b})$. The patterns of major adducts were similar to those obtained when salmon sperm DNA that had been reacted with the diol-epoxides in vitro was analyzed by the standard procedure (Figures $6 \mathrm{c}, \mathrm{d}$ ), although in the latter case some additional minor adduct spots were detected.

In order to determine the efficiency of adduct recovery using the nuclease $P_{1}$ modification of ${ }^{32} P$-postlabelling, adduct levels in the chemically-modified samples of salmon sperm DNA were determined by both that method and by the standard procedure. Qualitatively similar adduct patterns were obtained using either procedure, except that those spots indicated by arrows in Figure 


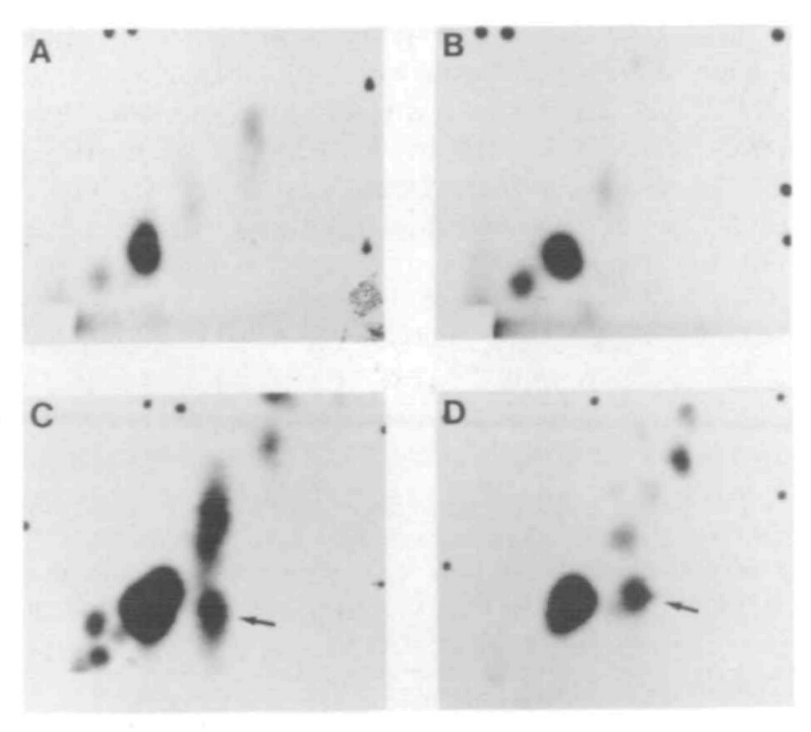

Fig. 6. Autoradiographs of polyethylene imine-cellulose thin layer chromatography maps of DNA adducts formed by reverse diol-epoxides of chrysene. A, DNA from V79 cells treated with anti-chrysene-3,4-diol 1,2-oxide; B, DNA from V79 cells treated with syn-chrysene-3,4-diol 1,2-oxide; C, salmon sperm DNA reacted with anti-chrysene-3,4-diol 1,2-oxide; D, salmon sperm DNA reacted with syn-chrysene-3,4-diol 1,2 -oxide. $A$ and $B$ were obtained using the nuclease $P_{1}$ modification of 32P-postlabelling, $C$ and D using the standard procedure. Similar profiles to $C$ and $D$ were obtained using the nuclease $P_{1}$ digestion procedure, except that those spots marked by arrows were not observed. Autoradiography was at $-75^{\circ} \mathrm{C}$ for 3.5 days (A and B) or at room temperature for $1.5 \mathrm{~h}$ (C and D). Autoradiographs of DNA from untreated V79 cells (showing no signals) and from cells treated with the bay-region oxides of chrysene and 3-hydroxychrysene were presented in a previous paper (4).
$6 c, d$ were not detected using the nuclease $P_{1}$ digestion procedure. In the case of the anti-diastereomer, maximum recovery of adducts was 6-fold lower using the nuclease $P_{1}$ procedure, whilst with the syn-diastereomer, maximum recovery was 1.4-fold lower. Using these ratios, values for the levels of adducts in the V79 cell DNA were estimated from the values obtained using the nuclease $\mathrm{P}_{1}$ digestion modification (Table II). Using linear regression analysis, the slopes of the concentrationresponse curves of the mutagenic effects and the adduct levels were determined. The ratio of these values amounted to 29 and 16 [mutations $/ 10^{6}$ cells per pmol adduct/mg DNA] for anti- and syn-chrysene-3,4-diol 1,2-oxide respectively. [The uncorrected figures were 41 and 95 (mutations $/ 10^{6}$ cells per pmol adduct $/ \mathrm{mg}$ DNA)]. Due to the weakness of the effects, the inaccuracy may be substantial. In a previous study (4), the bay-region diolepoxides produced 18 and 10 [mutations $/ 10^{6}$ cells per pmol adduct/mg DNA] for the anti- and syn-diastereomer respectively. It appears unlikely that the low mutagenicity in V79 cells for the reverse diol-epoxides, as compared to that of the bay-region diol-epoxides (Table $\mathrm{I}$, is due to low promutagenicity of their DNA adducts.

\section{Transformation of $M 2$ mouse prostate cells}

Chrysene-3,4-diol and its 1,2-oxides produced clear positive responses in the $\mathbf{M} 2$ cell transformation assay (Table III). Other chrysene derivatives were tested previously under the same experimental conditions (3), allowing quantitative comparisons. At their optimal concentrations, chrysene-3,4-diol and chrysene-1,2-diol induced similar numbers of foci $(0.7$ and $0.6 /$ dish). Taking into account the exposure concentrations, chrysene-3,4-diol was somewhat more potent [0.04

Table III. Malignant transformation of mouse C3H M2 cells by chrysene-3,4-diol and its vicinal diol-epoxides"

\begin{tabular}{|c|c|c|c|}
\hline Compound & $\begin{array}{l}\text { Concentration } \\
(\mu \mathrm{g} / \mathrm{ml})\end{array}$ & $\begin{array}{l}\text { Cloning } \\
\text { efficiency } \\
\text { (\%) }\end{array}$ & $\begin{array}{l}\text { No. of transformed } \\
\text { foci/no. of treated } \\
\text { dishes }\end{array}$ \\
\hline Control (acetone) & & 23 & $0 / 9$ \\
\hline \multirow[t]{2}{*}{$N$-Methyl- $N$-nitro- $N$-nitrosoguanidine } & 0.5 & 14 & $11 / 10$ \\
\hline & 1.0 & 8 & $13 / 15$ \\
\hline \multirow{3}{*}{ Chrysene-3,4-diol } & 20 & 21 & $3 / 5$ \\
\hline & 40 & 11 & $5 \pi$ \\
\hline & 80 & 5 & $0 / 2$ \\
\hline \multirow[t]{2}{*}{ anti-Chrysene-3,4-diol 1,2-oxide } & 0.5 & 27 & $0 / 12$ \\
\hline & 2 & 24 & $2 / 12$ \\
\hline \multirow[t]{5}{*}{ syn-Chrysene-3,4-diol 1,2-oxide } & 0.5 & 27 & $0 / 4$ \\
\hline & 2 & 25 & $3 / 11$ \\
\hline & 5 & 15 & $8 / 15$ \\
\hline & 10 & 2 & $0 / 15$ \\
\hline & 20 & 0 & - \\
\hline
\end{tabular}

"Data are a composite of two separate experiments. Compounds were dissolved in acetone (final concentration in the medium, 0.5\%), which was alkalized in the case of the diol-epoxides with triethylamine $(1: 1000, v / v)$. Results for further chrysene derivatives (including chrysene-1,2-diol, 9-hydroxychrysene-1,2-diol, and their bay-region oxides), published previously (3), are directly comparable, since the same methods were used, and the responses of the negative and positive controls were very similar. 
(foci $/ \mathrm{dish}) /(\mu \mathrm{mol} / \mathrm{ml})]$ than chrysene-1,2-diol $[0.02$ (foci/dish) $/(\mu \mathrm{mol} / \mathrm{ml})]$. syn-Chrysene-3,4-diol 1,2-oxide was also more active than the corresponding bay-region diol-epoxide. Both reverse diol-epoxides successfully transformed $\mathrm{M} 2$ cells [up to 0.5 foci/dish (Table III), as compared to $0.4,0.2,0.8$ and 0.2 foci/dish for anti- and syn-chrysene-1,2-diol 3,4-oxide, and antiand syn-9-hydroxychrysene-1,2-diol 3,4-oxide respectively (3)]. The reverse diol-epoxides however had to be used at relatively high concentrations. Thus, their potency was substantially lower than that of the anti-diastereomers of the bay-region diolepoxides of chrysene and 3-hydroxychrysene, but was similar to that of the syn-diastereomers of these bay-region diol-epoxides (Table I).

\section{Correlations between responses in different test systems}

All compounds showed positive responses in all 7 test systems. The potency of the most and the least active compounds, however, differed up to several hundred fold. Statistical analyses showed high correlations between the activities in the reversion assays in S.typhimurium strains TA100, TA97 and TA104, the SOS chromotest and the gene mutation test in V79 cells (Table IV). In contrast to this, the activity in S.typhimurium TA98 did not seem to correlate to that in any other system. The transformation activity in M2 cells did not correlate with the mutagenicity in S.typhimurium TA98, it showed moderate correlations with the mutagenicity in the other S.typhimurium strains, and it correlated relatively well with the activities in the SOS chromotest and in the mutagenicity assay in V79 cells.

\section{Discussion}

Chrysene-3,4-diol is metabolized in the presence of rat liver enzymes to mutagenic products. In the present study we demonstrated that the predominant metabolites of chrysene-3,4diol, namely the syn- and anti-diastereomers of its reverse oxide, are mutagenic as well. Metabolically activated chrysene-3,4-diol, as well as the authentic diol-epoxides in the absence of an activating system reverted $S$. typhimurium TA98 with very high efficiency, but showed only weak mutagenic activities in strain TA100 and in V79 cells. Furthermore, the presence of an inhibitor of microsomal epoxide hydrolase potentiated the mutagenicity of chrysene-3,4-diol, whereas the purified enzyme inactivated its vicinal oxides. These data provide strong evidence that these diol-epoxides indeed account for the mutagenicity of the metabolically activated dihydrodiols.

Nearly all investigated vicinal diol-epoxides are metabolized by microsomal epoxide hydrolase at insignificantly low rates, if at all $(2,22,30-36)$. The only known exceptions to this rule are the syn- and anti-diastereomers of benz [ $a$ ] anthracene-1,2-diol 3,4-oxide, which are moderately good substrates (36). In the

Table IV. Correlations between genotoxic and cell-transforming activities of chrysene diol-epoxides in different test systems"

\begin{tabular}{lrlllll}
\hline & TA98 & TA97 & TA100 & TA104 & SOS & V79 \\
\hline TA97 & 0.37 & & & & & \\
TA100 & 0.05 & 0.86 & & & & \\
TA104 & 0.05 & 0.91 & 0.97 & & & \\
SOS & 0.27 & 0.91 & 0.86 & 0.93 & & \\
V79 & -0.17 & 0.66 & 0.92 & 0.91 & 0.83 & \\
M2 & 0.07 & 0.38 & 0.56 & 0.59 & 0.70 & 0.78 \\
\hline
\end{tabular}

"Values are correlation coefficients ( $r$ ) from linear regression analyses of the logarithms of the specific activities, presented in Table $I$. present study, the list of diol-epoxides which are metabolized at an appreciable rate by microsomal epoxide hydrolase is extended by syn- and anti-chrysene-3,4-diol 1,2-oxides. They are isomers of the benz[ $a$ ]anthracene-1,2-diol 3,4-oxides, differing only in the anellation of the terminal benzo ring, which is linear in the benz $[a]$ anthracene derivatives, but angular in the chrysene derivatives.

The bay-region and reverse diol-epoxides of chrysene differed enormously in their mutagenicity spectrum in a series of 4 his $^{-}$ strains of $S$. typhimurium. For example, in strain TA100, antichrysene-3,4-diol 1,2-oxide showed only $5 \%$ of the activity of the corresponding bay-region diol-epoxide, but with strain TA98 the respective value was $790 \%$. The first evidence for bay-region activation of chrysene was provided by experiments in which the mutagenicity of all possible trans-dihydrodiols of chrysene was compared, using TA100 as the target strain (1). The authors would have come to a very different conclusion, if they had used strain TA98.

The Salmonella mutagenicity assay detects reversions of his strains. In each strain, only a small number of specific base sequence alterations lead to histidine prototrophy. Some mutagens may not induce the needed mutations and therefore may not be detected in the respective strain. The observation that the reverse diol-epoxides of chrysene transformed M2 cells, suggests that they can induce mutations which are of significance in carcinogenesis.

In mouse skin treated with chrysene-3,4-diol, no tumors were initiated (37) and no DNA adducts were detected (38). In newborn mice, pulmonary or hepatic tumors were not induced (39). While the protocols used are insufficient for classifying chrysene-3,4diol as a non-carcinogen, chrysene-1,2-diol was active under the same conditions. This difference between the isomeric dihydrodiols may be caused by differential detoxification of their active metabolites. In the present study the reverse diol-epoxides, but not the bay-region diol-epoxides, were inactivated by microsomal epoxide hydrolase. This enzyme appears to be ubiquitious in mammalian tissues, although at different levels (40). Its presence has also been demonstrated in numerous cultured mammalian cell lines, including V79 cells (41). In M2 cells its activity (measured with benzo[a]pyrene 4,5-oxide as the substrate) is about twice that found in V79 cells (H.R.Glatt, unpublished result). If the active species is added directly (rather than generated in the test organisms), detoxification systems may be exhausted by the use of high doses. This is particularly the case in vitro, where cell densities are low.

It has been predicted that the bay-region diol-epoxides are chemically more reactive than any other vicinal diolepoxide derived from the same polycyclic aromatic hydrocarbon (42). This prediction was based on quantum chemical calculations according to Dewar (43), yielding the highest $\Delta \mathrm{E}_{\text {delood }} / \beta$ values for the formation of the benzylic carbocations from bay-region diol-epoxides. In the present study, the half-lives of synchrysene-1,2-diol 3,4-oxide and syn-chrysene-3,4-diol 1,2-oxide agree with this prediction, but among the anti-diastereomers the reverse diol-epoxide was shorter-lived than the bay-region diol-epoxide. Moreover, whereas among previously investigated diol-epoxides the anti-diastereomers were more stable in buffer than their syn-configurated counterparts $(16,44)$, antichrysene-3,4-diol 1,2-oxide showed a much shorter half-life than its syn-diastereomer. The only other known exception to this empirical rule is the reverse diol-epoxides of benz[a] anthracene (17). A possible explanation for the reversal of reactivity in these 
two diastereomeric pairs is that the anti-diastereomer adopts an aligned conformation to a substantial percentage, as was also found for the analogous benz $[a]$ anthracene anti-diol-epoxide (17). Epoxides which exist in a rigid aligned conformation are considered to be more reactive under neutral conditions compared to those adopting a nonaligned conformation (45).

\section{Acknowledgements}

We thank Uschi Marine, Karin Pauly and Andrea Pibe for their excellent tectmical assistance. This work was financially supported by the Deutsche Forschungsgemeinschaft (SFB 302) and, in part, by Grant No. CA21959 awarded by the National Cancer Institute, DHHS. Sabine Elsberg was a recipient of a stipend from CliussenStiftung im Stiftervertand der Deutschen Wissenschaft.

\section{References}

1. Wood,A.W., Levin,W., Ryan,D., Thomas,P.E., Yagi,H., Mah,H.D., Thakker,D.R., Jerina,D.M. and Conney,A.H. (1977) High mutagenicity of metabolically activated chrysene 1,2-dihydrodiol: evidence for bay region activation of chrysene. Biochem Biophys. Res. Commun., 78, 847-854.

2. Wood,A.W., Chang,R.L., Levin,W., Ryan,D.E., Thomas,P.E., Mah,D.H., Karle,J.M., Yagi,H., Jerina,D.M. and Conney,A.H. (1979) Mutagenicity and tumorigenicity of phenanthrene and chrysene epoxides and diol-epoxides. Cancer Res., 39, 4069-4077.

3. Glatt,H.R., Seidel,A., Bochnitschek,W., Marquardt,H., Marquardt,H., Hodgson, R.M., Grover,P.L. and Oesch,F. (1986) Mutagenic and celltransforming activities of triol-epoxides as compared to other chrysene metabolites. Cancer Res., 46, 4556-4565.

4. Phillips,D.H., Glatt,H.R., Seidel,A., Bochnitschek,W., Oesch,F. and Grover,P.L. (1986) Mutagenic potential and DNA adducts formed by diolepoxides, triol-epoxides and $\mathrm{K}$-region epoxide of chrysene in mammalian cells. Carcinogenesis, 7, 1739-1743.

5. Nordqvist,M., Thakker,D.R., Vyas,K.P., Yagi,H., Levin, W., Ryan,D.E., Thomas,P.E., Conney,A.H. and Jerina,D.M. (1981) Metabolism of chrysene and phenanthrene to bay-region diol epoxides by rat liver enzymes. Mol. Pharmacol., 19, 168-178.

6. Jacob,J., Schmoldt,A. and Grimmer,G. (1982) Formation of carcinogenic and inactive chrysene metabolites by rat liver microsomes of various monooxygenase activities. Arch. Taxicol., 51, 255-265.

7. Jacob,J., Schmoldt,A., Hamann,M., Raab,G. and Grimmer,G. (1987) Monooxygenase induction by various xenobiotics and its influence on rat liver microsomal metabolism of chrysene in comparison to benz [a]anthracene. Cancer Lett., 34, 91-102.

8. Jacob,J., Grimmer,G., Raab,G., Emura,M., Riebe,M. and Mohr,U. (1987) Comparison of chrysene metabolism in epithelial human bronchial and Syrian hamster lung cells. Cancer Lett., 38, 171-180.

9. Chou,M.W., Fu,P.P. and Yang,S.K. (1981) Metabolic conversion of dibenz $[a, h]$ anthracene (+)-trans-1,2-dihydrodiol and chrysene (+)trans-3,4-dihydrodiol to vicinal dihydrodiol epoxides. Proc. Nath Acad. Sci. USA, 78, 4270-4273.

10. Vyas,K.P., Yagi,H., Levin,W., Conney,A.H. and Jerina,D.M. (1981) Metabolism of (-)-trans-(3R,4R)-dihydroxy-3,4-dihydrochrysene to diol epoxides by liver microsomes. Biochem. Biophys. Res. Commun., 98, $961-969$.

11. Wameling,C., Glatt,H.R., Oesch,F., and Seidel,A. (1992) Stereospecific synthesis of the diastereomeric 'reverse' dihydrodiol epoxides of chrysene and picene. Polycyclic Aromatic Comp., in press.

12. Seidel,A., Bochnitschek,W., Glatt,H.R., Hodgson,R.M., Grover,P.L. and Oesch,F. (1991) Activated Metabolites of chrysene: synthesis of 9-hydroxychrysene-1,2-diol and the corresponding bay-region syn- and anti-triolcpoxides. In Cooke,M., Loening,K. and Merritt,J. (ods), Pohnnuclear Aromatic Hydrocarbons: Measurements, Means, and Metabolism, Battelle Press, Columbus $\mathrm{OH}$, pp. 801-817.

13. Seidel, A. (1989) $\mathrm{PhD}$. Thesis, University of Mainz.

14. Platt,K.L. and Oesch,F. (1983) Efficient synthesis of non-K-region transdihydrodiols of polycyclic aromatic hydrocarbons from o-quinones and catechols. J. Org. Chem., 48, 265-268.

15. Adam,W., Curci,R. and Edwards,J.O. (1989) Dioxiranes: a new class of powerful oxidants. Acc. Chem. Res., 22, 205-211.

16. Glat,,H.R., Piee,A., Pauly,K., Steinbrecher,T., Schrode,R., Oesch,F. and Seidel,A. (1991) Fjord- and bay-region diol-epoxides investigated on stability, SOS induction in Escherichia coli, and mutagenicity in Sabmonella typhimurivon and mammalian cells. Cancer Res., 51, 1659-1667.

17. Sayer,J.M., Whalen,D.L., Friadman,S.L., Paik,A., Yagi,H., Vyas,K.P. and Jerina,D.M. (1984) Conformational effects in the hydrolyses of benzo-ring diol epoxides that have bay-region diol groups. J. Am. Chem. Soc., 106, $226-233$.

18. Lehr,R.L., Kumar,S., Levin,W., Wood,A.W., Chang,R.L., Conney,A.H., Yagi,H., Sayer,J.M. and Jerina,D.M. (1985) The bay-region theory of polycyclic aromatic hydrocarbon carcinogenesis. In Harvey,R.G. (ed.), Polycyclic Hydrocarbons and Carcinogenesis, ACS Symposium Series 283, American Chemical Society, Washington, DC, pp. 63-84.

19. Bentley,P. and Oesch,F. (1975) Purification of rat liver epoxide hydrolase to apparent homogeneity. FEBS Lett., 59, 291-295.

20. Maron,D.M. and Ames, B.N. (1983) Methods for detecting carcinogens and mutagens with the Salmonella/mammalian microsome mutagenicity test. Mutat. Res., 113, 173-215.

21. Oesch,F., Kaubisch, N., Jerina,D.M. and Daly,J.W. (1971) Hepatic epoxide hydrase, structure-activity relationships for substrates and inhibitors. Biochemistry, 10, 4858-4866.

22. Glatt,H.R., Cooper,C.S., Grover,P.L., Sims,P., Bentley,P., Merdes,M., Waechter,F., Vogel,K., Guenthner,T.M. and Oesch,F. (1982) Inactivation of a diol-epoxide by dihydrodiol dehydrogenase, but not by two epoxide hydrolases. Science, 215, 1507-1509.

23. Glatt,H.R. (1989) Mutagenicity spectra in Salmonella typhimurium strains of ghutathione, L-cysteine and active oxygen species. Mutagenesis, 4, 221-227.

24. Quillardet,P, and Hofnung,M. (1985) The SOS chromotest, a colorimetric bacterial assay for genotoxins: procedures. Mutat. Res., 147, 65-78.

25. Glatt,H.R., Harvey,R.G., Phillips,D.H., Hewer,A. and Grover,P.L. (1989) Influence of the alkyl substituent on mutagenicity and covalent DNA-binding of bay-region diol-epoxides of 7-methyl- and 7-ethylbenz[a]anthracene in Salmonella and V79 Chinese hamster cells. Cancer Res., 49, 1778-1782.

26. Marquart, $H$. (1976) Malignant transformation in vitro: a model system to study mechanisms of action of chemical carcinogens and to evaluate the oncogenic potential of environmental chernicals. In Montesano, R., Bartsch, H. and Tomatis,L. (eds), Screening Tesss of Chemical Carcinogens, LRC Scientific Publication No. 12, International Agency for Research on Cancer, Lyon, France, pp. $389-410$.

27. Gupta,R.C. (1984) Nonrandom binding of the carcinogen $N$ hydroxy-2-acetylamino-fluorene to repetitive sequences of rat liver DNA in vivo. Proc. Natl. Acad. Sci. USA, 81, 6943-6947.

28. Reddy,M.V. and Randerath,K. (1986) Nuclease $P_{1}$-mediated enhancement of ${ }^{32} \mathrm{P}$-postlabeling test for stnucturally diverse DNA adducts. Carcinogenesis, 7, $1543-1551$.

29. Everson,R.B., Randerath,E., Santella,R.M., Cefalo,R.C., Avitts,T.A. and Randerath,K. (1986) Detection of smoking-related covalent DNA adducts in human placenta. Science, 231, 54-57.

30. Glatt,H.R. and Oesch,F. (1986) Structural and metabolic parameters governing the mutagenicity of polycyclic aromatic hydrocarbons. In de Serres,F.J. (ed), Chentical Mutagens: Principles and Methods for Their Detection, Plenum Press, New York, vol. 10, pp. 73-127.

31. Wood,A.W., Levin, W., Lu,A.Y.H., Yagi,H., Hernandez,O., Jerina,D.M. and Conney,A.H. (1976) Metabolism of benzo[ $a]$ pyrene and benzo[a]pyrene derivatives to mutagenic products by highly purified hepatic microsomal enzymes. J. Biol. Chem., 251, 4882-4890.

32. Wood,A.W., Wislocki,P.G., Chang,R.L., Levin,W., Lu,A.Y.H., Yagi,H., Hernandez,O., Jerina,D.M. and Conney,A.H. (1976) Mutagenicity and cytotoxicity of benzo[a]pyrene benzo-ring epoxides. Cancer Res., 36, $3358-3366$.

33. Wood,A.W., Chang,R.L., Levin,W., Lehr,R.E., Schaefer-Ridder,M., Karle,J.M., Jerina,D.M. and Conney,A.H. (1977) Mutagenicity and cytotoxicity of benz $[a]$ anthracene diol epoxides and tetrahydro-epoxides: exceptional activity of the bay region 1,2-epoxides. Proc. Natl. Acad. Sci. USA, 74, $2746-2750$.

34. Wood,A.W., Chang,R.L., Levin,W., Ryan,D.E., Thomas,P.E., CroisyDelcey,M., Ittah, Y., Yagi,H., Jerina,D.M. and Conney,A.H. (1980) Mutagenicity of the dihydrodiols and bay-region diol-epoxides of benzo[c]phenanthrene in bacterial and mammalian cells. Cancer Res., 40, 2876-2883.

35. Wood,A.W., Chang,R.L., Levin,W., Ryan,D.E., Thomas,P.E., Lehr,R.E., Kumar,S., Sardella,D.J., Boger,E., Yagi,H., Sayer,J.M., Jerina,D.M. and Conney,A.H. (1981) Mutagenicity of the bay-region diol-epoxides and other benzo-ring derivatives of dibenzo $[a, h]$ pyrene and dibenzo $[a, i]$ pyrene. Cancer Res., 41, 2589-2597.

36. Sayer,J.M., Yagi,H., van Bladeren,P.J., Levin,W. and Jerina,D.M. (1985) Stereoselectivity of microsomal epoxide hydrolase toward diol expoxides and tecrahydroepoxides derived from benz[a]anthracene. J. Biol Chem., 260, $1630-1640$.

37. Levin,W., Wood,A.W., Chang,R.L., Yagi,H., Mah,H.D., Jerina,D.M. and Conney, A.H. (1978) Evidence for bay region activation of chrysene 1,2-dihydrodiol to an ultimate carcinogen. Cancer Res., 38, 1831-1834. 38. Phillips,D.H., Hewer, A. and Grover,P.L. (1987) Formation of DNA adducts 
in mouse skin treated with metabolites of chrysene. Cancer Letr., 35, 207-214.

39. Buening,M.K., Levin,W., Karle,J.M., Yagi,H., Jerina,D.M. and Conney,A.H. (1979) Tumorigenicity of bay region epoxides and other derivatives of chrysene and phenamthrene in newbom mice. Cancer Res., 39, 5063-5068.

40. Glatt,H.R., Mertes,I., Wolfel,T. and Oesch,F. (1984) Epoxide hydrolases in laboratory animals and in man. In Greim,H., Jung,R., Kramer,M., Marquardt, H. and Oesch,F. (ods), Biachemical Basis of Chemical Carcinogenesis, Raven Press, New York, pp. 189-203.

41. Glatt,H.R., Gempertein,I., Setiabudi,F., Platt,K.L. and Oesch,F. (1990) Expression of xenobiocic-metabolizing enzymes in propagatable cell cultures and induction of micronuclei by 13 compounds. Mutagenesis, 5, $241-249$.

42. Jerins,D.M. and Lehr,R.E. (1977) The bay-region theory: a quantum mechanical approach to aromatic hydrocarbon-induced carcinogenicity. In Ullich,V., Roots,I., Hildebrandt,A., Estabrook, R.W. and Conney,A.H. (eds), Micrasomes and Drug Oxidations, Pergamon Press, Oxford, pp. 709-720.

43. Dewar,M.J.S. (1969) The Molecular Orbital Theory of Organic Chemistry. McGraw-Hill, New York.

44. Sayer,J.M., Lehr,R.E., Whaten,D.L., Yagi,H. and Jerina,D.M. (1982) Structure activity indioes for the hydrolysis of diol-epoxides of polycyclic aromatic hydrocarbons. Tetrahedron Lett., 23, 4431-4434.

45. Sayer,J.M., Yagi,H., Silverton,J.V., Friedman,S.L., Whalen,D.L. and Jerina,D.M. (1982) Conformational effects in the hydrolyses of rigid berzylic epoxides: implications for diol epoxides of polycyclic hydrocarbons. J. Am. Chem. Soc., 104, 1972-1978.

Received on July 29, 1992; revised on Octaber 16, 1992; accepted on October 22, 1992 